\title{
ANALISIS SEDIMENTASI LAGUNA SEGARA ANAKAN DENGAN PEMODELAN NUMERIK ANGKUTAN SEDIMEN KOHESIF
}

\section{SEDIMENTATION ANALYSIS OF SEGARA ANAKAN LAGOON USING COHESIVE SEDIMENT TRANSPORT NUMERICAL MODELLING}

\author{
Irham Adrie Hakiki1)*, Leo Eliasta Sembiring2), Cahyo Nur Rahmat Nugroho') \\ 1)Balai Teknik Pantai, Kementerian PUPR \\ Jl. Gilimanuk Singaraja KM122, Buleleng, Bali, Indonesia \\ 2)Subdirektorat Perencanaan Teknis Sungai dan Pantai, Kementerian PUPR \\ Jl. Pattimura No. 20 Kebayoran Baru, Jakarta Selatan, Indonesia \\ *Correspondent email: adriehakiki@pu.go.id
}

Diterima: 10 Agustus 2020; Direvisi: 20 April 2021; Disetujui: 11 Juni 2021

\begin{abstract}
Sagara Anakan Lagoon has been continuously receded caused by the high sedimentation rate. The deposited sediment volume was predicted to be around 1 million $\mathrm{m}^{3} /$ year. This phenomenon, if not treated will harm the existing ecosystem and also could cause many kinds of its native biota extinct. Engineering could be applied to prevent it. However, the transport and sedimentation pattern must be known for it to be effective. Silting in Sagara Anakan Lagoon simulated by using MIKE21 numerical model which could simulate sediment transport in 2D horizontal scheme. The deposited sediment, mainly consisted of mud, so the model must be capable for simulating cohesive sediment transport. Model is set to simulate one year of morphological event which reached with the usage of time speed up acceleration factor. Model calibrated to be able to simulate a deposition event in the order of one million $\mathrm{m}^{3} /$ year. Model calibrated by tuning critical bed shear stress for deposition $\left(\tau_{c d}\right)$ and erosion $\left(\tau_{c e}\right)$ parameters as a base for sensitivity analysis. Model result shown that the sedimentation in Sagara Anakan Lagoon is caused by asymmetry of flood and ebb current. Major siltation happened around the delta with the maximum and mean observed bed change are approximately $0.6 \mathrm{~m}$ and $0.16 \mathrm{~m}$ respectively. The setup for this model could be used as a base model for planning an engineering approach for controlling sediment in Sagara Anakan Lagoon.
\end{abstract}

Keywords: Numerical model, cohesive sediment, mud transport, estuary modelling

\begin{abstract}
ABSTRAK
Laguna Segara Anakan secara berkesinambungan mengalami degradasi luas akibat tingkat pengendapan yang tinggi. Jumlah sedimen yang mengendap diperkirakan sekitar 1 juta $\mathrm{m}^{3} /$ tahun. Penyusutan luas laguna Segaran Anakan jika dibiarkan akan mengakibatkan rusaknya ekosistem dan menghilangkan keragaman biota yang ada saat ini. Rekayasa teknis dapat dilakukan untuk mencegah hal tersebut. Namun, untuk melakukan prenencanaan yang efektif, pola sebaran dan pengendapan sedimen yang terjadi perlu diketahui. Pendangkalan di Laguna Segara Anakan dimodelkan menggunakan model numerik MIKE21 untuk menyimulasikan angkutan sedimen dalam skema 2D horizontal. Sedimen yang masuk ke kawasan Segara Anakan didominasi oleh lumpur, maka model yang digunakan harus dapat menyimulasikan angkutan sedimen kohesif.. Periode simulasi morfologi model adalah satu tahun dengan menerapkan faktor percepatan waktu. Model dikalibrasi untuk dapat menyimulasikan kejadian pengendapan di laguna dengan volume sebesar 1 juta $\mathrm{m}^{3} /$ tahun. Kalibrasi model dilakukan dengan analisis sensitivitas pada parameter tegangan dasar kritis untuk deposisi $\left(\tau_{c d}\right)$ dan erosi $\left(\tau_{c e}\right)$. Hasil model numerik ini menunjukkan sedimentasi di Laguna Segara Anakan diakibatkan oleh asimetri kecepatan aliran pasang dan surut. Pengendapan terbanyak terjadi pada daerah delta dengan pengendapan maksimum sekitar 0,6 $\mathrm{m}$ dan rata - rata pengendapannya berkisar 0,16 $\mathrm{m}$. Pengaturan pada model ini dapat digunakan sebagai dasar untuk menguji rencana penanganan sedimentasi di Laguna Segara Anakan dengan rekayasa teknik pengendalian sedimen.
\end{abstract}

Kata Kunci: Model numerik, sedimen kohesif, transpor lumpur, pemodelan estuari

DOI: https://doi.org/10.32679/jth.v12i1.642

(c) Bintek SDA, Dirjen SDA, Kementerian PUPR Naskah ini di bawah kebijakan akses terbuka dengan lisensi CC-BY-SA (https://creativecommons.org/licenses/by-sa/4.0/) 


\section{PENDAHULUAN}

Segara Anakan merupakan laguna di antara Pulau Jawa dan Pulau Nusakambangan, Kabupaten Cilacap. Kondisi Segaran Anakan yang unik membuat ekosistem Segara Anakan memiliki keragaman biota yang ada (White et al, 1989). Kawasan ini juga menjadi penghubung pergerakan ekonomi dan sarana transportasi air masyarakat dari Cilacap menuju Pangandaran.

Laguna Segara Anakan secara berkesinambungan mengalami degradasi akibat tingkat pengendapan yang tinggi (Ardli, 2008; Sari, 2016; White et al, 1989). Adanya pengendapan pada perairan tersebut telah mengakibatkan terjadinya pendangkalan serta penyempitan luasan (Gambar 1). Luas perairan Laguna Segara Anakan tahun 1903 sebesar 6.450 ha. Namun pada tahun 1939 berkurang menjadi 6.060 ha. Sekitar tahun 1971, luas Segara Anakan menyusut kembali menjadi 4.290 ha. Hal ini terus berlanjut hingga pada tahun 1984, luas laguna menjadi 2.906 ha. Jumlah itu, pada tahun 1994, atau 10 tahun kemudian, menyusut menjadi 1.575 ha. Penyusutan masih terus terjadi sehingga pada tahun 2003, menjadi 600 ha. Dalam kurun waktu 19 tahun, terjadi penyusutan luasan
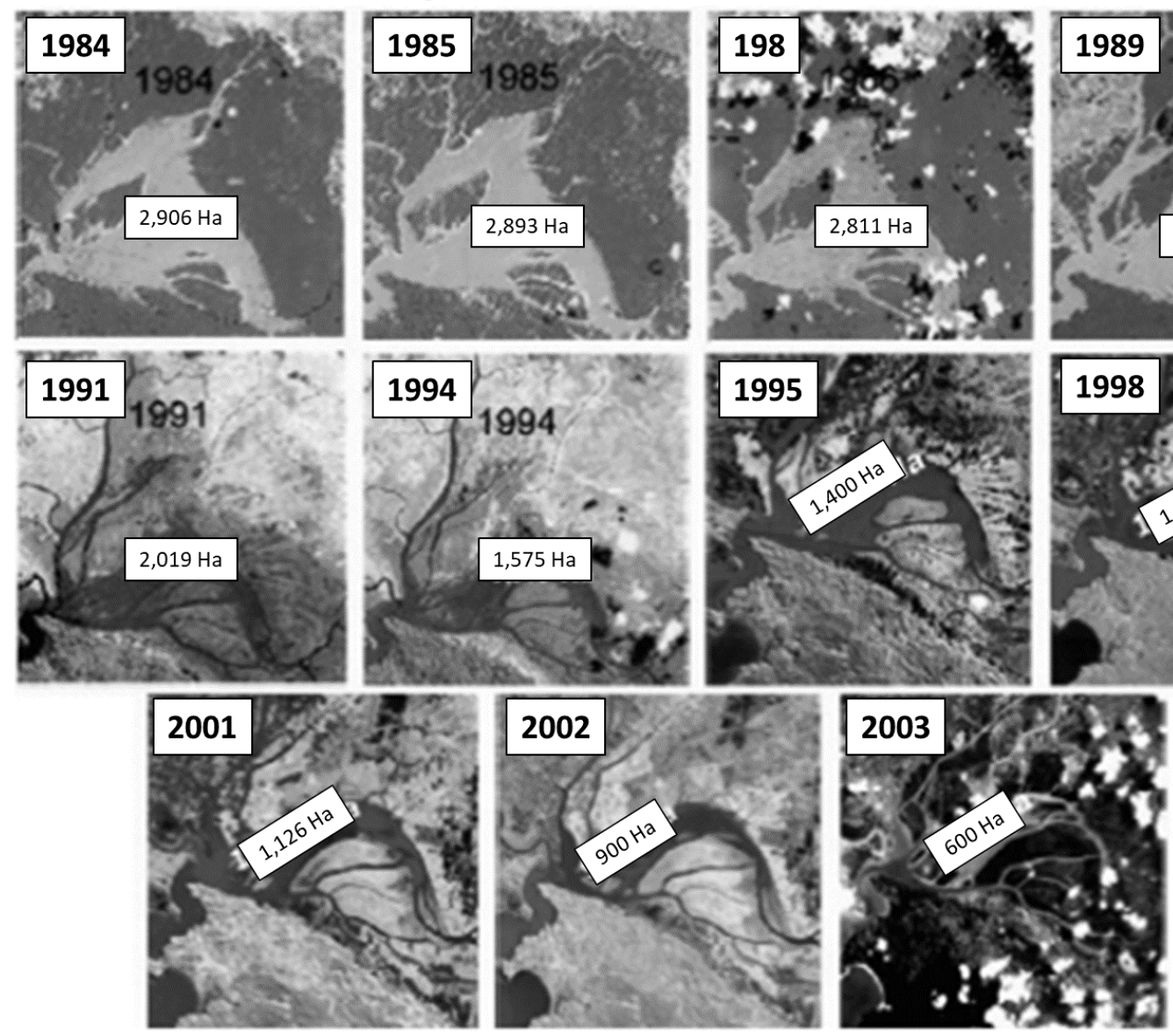
model numerik.
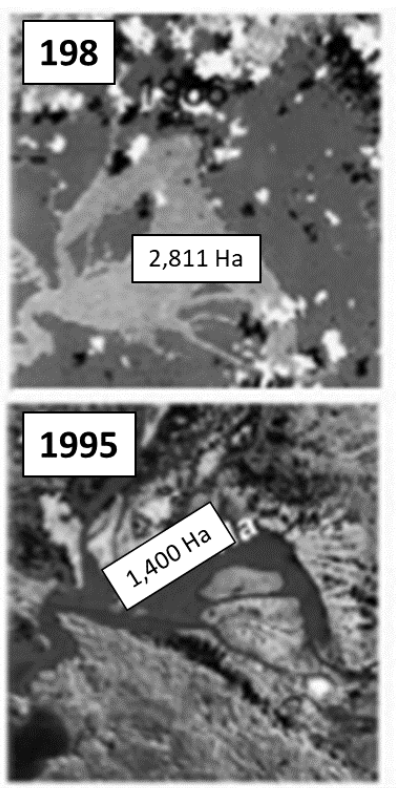

laguna 2.306 ha atau 121,4 ha per tahun. Penyusutan laguna Segara Anakan terutama disebabkan tingginya materi sedimen masuk ke dalam laguna. Diperkirakan besarnya sedimen yang masuk dari Sungai Citanduy sebesar 8,05 juta ton/tahun, Sungai Cimeneng sebesar 0,87 juta ton /tahun dan Sungai Cikonde 0,22 juta ton/tahun, dengan total pasokan sedimen 9,14 juta ton/tahun (BBWS Citanduy, 2012). Dari total sedimen yang masuk ke Segara Anakan, volume sedimen yang mengendap diperkirakan sekitar 1 juta $\mathrm{m}^{3} /$ tahun (Binnie Black \& Veatch Ltd, 2000). Penyusutan Laguna Segaran Anakan telah menyebabkan perubahan ekosistem dan berpotensi menghilangkan keragaman biota yang ada saat ini (Ardli dan Wolff, 2009). Dengan mengetahui pola sebaran sedimen dan pengendapannya, penyusutan Laguna Segara Anakan dapat direkonstruksi dengan

Material sedimen yang masuk ke kawasan Segara Anakan didominasi oleh lumpur. Lumpur termasuk ke dalam sedimen kohesif yang bersifat memiliki butiran halus dan dapat
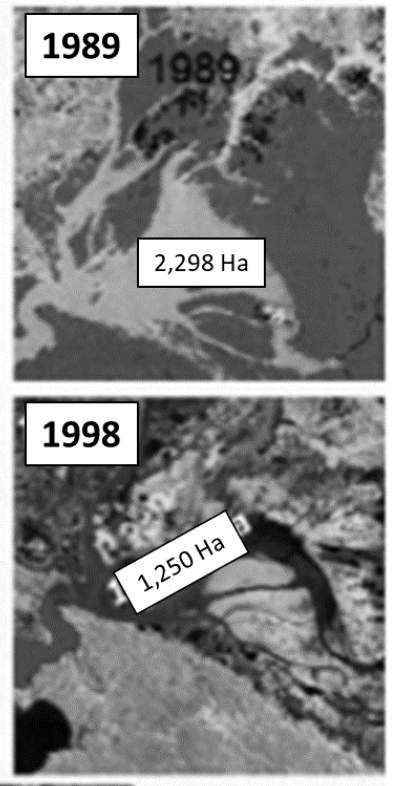

(Sumber: BBWS Citanduy, 2012)

Gambar 1 Penyusutan Laguna Segara Anakan 
berikatan dengan butir lainnya sehingga ukuran butirannya menjadi lebih besar. Oleh karena itu, model yang digunakan harus mampu menyimulasikan sedimen kohesif.. Sedimen kohesif sangat ringan sehingga mudah terbawa jauh oleh aliran dan lebih sulit terendapkan (Postma, 1967).

Pemodelan aliran dalam membawa material dan pengendapannya menyimulasikan kejadian aliran dalam menyebarkan sedimen. Oleh karenanya, dalam pemodelan ini model hidrodinamika menjadi penggerak utamanya karena perhitungan dari pergerakan massa air yang dilakukan memberikan keluaran berupa kecepatan aliran dan elevasi muka air yang kemudian digunakan dalam proses transpor sedimen. Proses transportasi sedimen kohesif pada kolom air disimulasikan pada model dengan persamaan adveksi - dispersi (Lumborg dan Windelin, 2003).

Pada tulisan ini akan disampaikan pola persebaran sedimen dan titik - titik yang mengalami pengendapan di Laguna Segara Anakan dengan model numerik 2DH (2 dimensi horizontal) beserta metode kalibrasinya. Hasil studi ini direncanakan sebagai model dasar studi metode rekayasa teknik untuk menanggulangi sedimentasi di Laguna Segara Anakan.

\section{METODOLOGI}

\section{Gambaran Umum dan Data Pendukung}

Segara Anakan merupakan tempat bermuaranya Sungai Citanduy, Sungai Cibereum, Sungai Cimeneng, Sungai Cikonde, dan Sudetan Cimeneng. Erosi tinggi terjadi di DAS Citanduy, DAS Cimeneng, dan Cikonde dengan prakiraan jumlah sedimen yang terbawa sebesar 5,77 juta $\mathrm{m}^{3} /$ tahun dengan prakiraan yang mengendap di Laguna Segara Anakan sebesar 1 juta $\mathrm{m}^{3} /$ tahun dengan sedimen yang didominasi oleh fraksi kohesif (BBWS Citanduy, 2012).

Kejadian pengendapan sedimen tersebut disumulasikan dengan model numerik MIKE21 dengan modul hidrodinamik (HD) dan modul angkutan lumpur (MT). Secara umum proses sebaran sedimen yang digunakan pada MIKE 21 mengikuti proses transportasi sedimen yang dijabarkan oleh Mehta et al (1989) dan alur pemodelan pada kajian ini ditunjukkan pada Gambar 2.

Model hidrodinamik (HD) sebagai model dasar yang menjadi penggerak model angkutan lumpur (MT), dibangun dengan syarat batas pasang surut pada kondisi batas laut dan debit pada kondisi batas sungai. Data pasang surut yang digunakan pada model diperoleh dari model pasang surut TOPEX/POSEIDON (Egbert et al, 1994). Pengukuran elevasi muka air dilakukan pada tiga titik pengamatan yang diukur secara manual menggunakan mistar pasang surut dengan interval ukur 1 jam selama $15 \times 24$ jam yang diamati pada tanggal 21 Mei 2016 - 5 Juni 2016. Titik pengamatan berada di Karanganyar, Kelaces, dan Pelataran Agung seperti ditunjukkan pada Gambar 3.

Dalam pembangunan model numerik ini digunakan data bathimetri pada wilayah laguna yang didapatkan dari hasil survei yang dilaksanakan oleh Balai Litbang Pantai pada tahun 2016 dan dikombinasikan dengan data dari GEBCO (General Bathymetric Chart of Ocean) dengan resolusi 30 arc second atau $1 \mathrm{~km}$ di ekuator, untuk mengisi kekosongan data di domain model yang mencakup wilayah laut lepas.

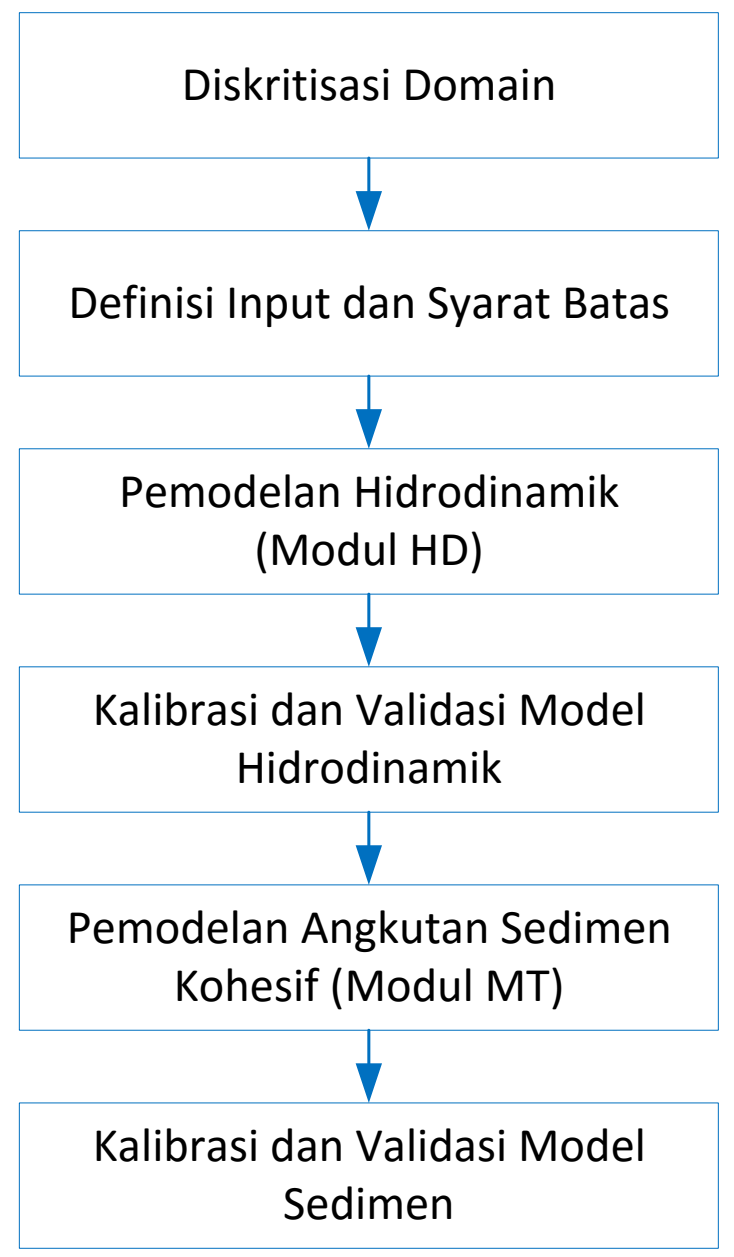

Gambar 2 Alur Pemodelan Numerik

Selain pasang surut, proses hidrodinamika Laguna Segara Anakan dipengaruhi juga oleh sungai - sungai yang bermuara di laguna. Pada model ini hanya sungai - sungai yang berdebit besar yang dimasukkan sebagai syarat batas bagi model yaitu 
Sungai Citanduy, Sungai Cibereum dan Sungai Cimeneng. Dalam memperoleh model yang realistis untuk simulasi satu tahun, maka dipilih nilai debit sungai yang dapat merepresentasikan debit sungai tersebut dalam satu tahun.

Nilai debit sungai mengacu dari hasil Studi Pantai dan Hidraulik Proyek Konservasi dan Pengembangan Segara Anakan (Binnie Black \& Veatch Ltd, 2000). Input debit pada model antara lain Sungai Citanduy $150 \mathrm{~m}^{3} / \mathrm{s}$, Sungai Cibereum $100 \mathrm{~m}^{3} / \mathrm{s}$, dan Sungai Cimeneng $15 \mathrm{~m}^{3} / \mathrm{s}$.

Dari ketiga sungai yang dimodelkan, pemasok sedimen terbanyak adalah Sungai Citanduy. Oleh karenanya, pada model sebaran sedimen hanya Sungai Citanduy yang diasumsikan sebagai sumber yang memberikan pasokan sedimen pada model. Konsentrasi sedimen layang yang diinputkan pada model adalah $0,326 \mathrm{~kg} / \mathrm{m}^{3}$ (White et al, 1989) sebagai nilai yang merepresentasikan suplai sedimen dari Sungai Citanduy ke Laguna Segara Anakan selama 1 tahun.

Konsentrasi sedimen layang yang masuk ke wilayah laguna dibandingkan dengan hasil pengukuran lapangan yang dilakukan oleh Puslitbang Sumber Daya Air (2016) pada tanggal 12 - 14 April 2016. Hasil dibandingkan dengan cara meninjau rentang nilai hasil model dengan orde hasil pengukuran data lapangan. Resume data hasil pengukuran sampel sedimen disajikan pada Gambar 3.

\section{Model Numerik Hidrodinamika}

Persamaan pengatur pada model hidrodinamika adalah persamaan kontinuitas dan persamaan momentum (DHI, 2012a). Persamaan kontinuitas tersebut:

$\frac{\partial h}{\partial t}+\frac{\partial h \bar{u}}{\partial x}+\frac{\partial h \bar{v}}{\partial y}=h S$

dan persamaan momentum untuk dua komponen horizontal $\mathrm{x}$ dan $\mathrm{y}$ dalam sumbu 2 dimensi horizontal:

$\frac{\partial h \bar{u}}{\partial t}+\frac{\partial h \bar{u}^{2}}{\partial x}+\frac{\partial h \overline{v u}}{\partial y}=f \bar{v} h-g h \frac{\partial \eta}{\partial x}-\frac{h}{\rho_{0}} \frac{\partial p_{a}}{\partial x}-\frac{g h^{2}}{2 \rho_{0}} \frac{\partial \rho}{\partial x}+$

$\frac{\tau_{s x}}{\rho_{0}}-\frac{\tau_{b x}}{\rho_{0}}-\frac{1}{\rho_{0}}\left(\frac{\partial s_{x x}}{\partial x}+\frac{\partial s_{x y}}{\partial y}\right)+\frac{\partial}{\partial x}\left(h T_{x x}\right)+\frac{\partial}{\partial y}\left(h T_{x y}\right)+$ $h u_{S} S$......

$\frac{\partial h \bar{v}}{\partial t}+\frac{\partial \overline{u v}}{\partial x}+\frac{\partial h \bar{v}^{2}}{\partial y}=-f \bar{u} h-g h \frac{\partial \eta}{\partial y}-\frac{h}{\rho_{0}} \frac{\partial p_{a}}{\partial y}-\frac{g h^{2}}{2 \rho_{0}} \frac{\partial \rho}{\partial y}+$

$\frac{\tau_{s y}}{\rho_{0}}-\frac{\tau_{b y}}{\rho_{0}}-\frac{1}{\rho_{0}}\left(\frac{\partial s_{y x}}{\partial x}+\frac{\partial s_{y y}}{\partial y}\right)+\frac{\partial}{\partial x}\left(h T_{x y}\right)+$

$\frac{\partial}{\partial y}\left(h T_{y y}\right)+h v_{s} S$

Dimana:

$\bar{u}, \bar{v}=\quad \begin{aligned} & \text { komponen kecepatan arus rata- } \\ & \text { rata terhadap kedalaman (depth }\end{aligned}$ averaged velocity) pada arah $\mathrm{x}$

(mengarah ke timur) dan y

(mengarah ke utara) (m/s)

$h=$ kedalaman perairan total $(\mathrm{m})$

$t=$ waktu (s)

$p_{a} \quad=$ tekanan atmosfer $\left(\mathrm{N} / \mathrm{m}^{2}\right)$

$\rho \quad=\quad$ massa jenis air $\left(\mathrm{kg} / \mathrm{m}^{3}\right)$

$\rho_{0} \quad=$ massa jenis air refernsi $\left(\mathrm{kg} / \mathrm{m}^{3}\right)$

$g=$ percepatan gravitasi $\left(\mathrm{m} / \mathrm{s}^{2}\right)$

$\eta \quad=\quad$ elevasi muka $\operatorname{air}(\mathrm{m})$

$S=$ suku source

$\tau_{s x}, \tau_{s y}=$ tegangan permukaan air $\left(\mathrm{N} / \mathrm{m}^{2}\right)$

$\tau_{b x}, \tau_{b y}=$ tegangan dasar $\left(\mathrm{N} / \mathrm{m}^{2}\right)$

$f \quad=$ parameter koriolis $(2 \Omega \sin \Phi)\left(\mathrm{s}^{-1}\right)$

$\Omega \quad=$ laju angular revolusi $\left(\mathrm{s}^{-1}\right)$

$\Phi \quad=$ garis lintang geografis $\left(^{\circ}\right)$

$T_{i j} \quad=$ tegangan lateral $\left(\mathrm{N} / \mathrm{m}^{2}\right)$

$s_{i j} \quad=$ tegangan radiasi $\left(\mathrm{m}^{3} / \mathrm{s}^{2}\right)$

\section{Model Numerik Sebaran Sedimen Kohesif}

Sedimen kohesif memiliki butiran halus dan dapat berikatan dengan butir lainnya sehingga ukuran butirannya menjadi lebih besar. Sedimen kohesif sangat ringan sehingga mudah terbawa jauh oleh aliran dan lebih sulit terendapkan (Postma, 1967). Kaitan aliran dengan sebaran sedimen dinyatakan dalam proses adveksi - dispersi yang memiliki persamaan pengatur sebagai berikut (DHI, 2012b):

$\frac{\partial \underline{c}}{\partial t}+u \frac{\partial \underline{\underline{c}}}{\partial x}+v \frac{\partial \underline{\underline{c}}}{\partial y}=\frac{1}{h} \frac{\partial}{\partial t}\left(h D_{x} \frac{\partial \underline{\underline{c}}}{\partial x}\right)+\frac{1}{h} \frac{\partial}{\partial t}\left(h D_{y} \frac{\partial \underline{c}}{\partial y}\right)+$ $Q_{L} C_{L} \frac{1}{h}-S$

Dimana:

$$
\begin{array}{lll}
\underline{c} & = & \text { konsentrasi rata }- \text { rata kedalaman } \\
& \left(\mathrm{g} / \mathrm{m}^{3}\right) \\
u, v & = & \text { kecepatan aliran rata }- \text { rata } \\
& \text { kedalaman }(\mathrm{m} / \mathrm{s}) \\
D_{x}, D_{y}= & \text { koefisien dispersi }\left(\mathrm{m}^{2} / \mathrm{s}\right) \\
h & = & \text { kedalaman perairan }(\mathrm{m}) \\
\mathrm{S} & = & \text { suku deposisi/erosi }\left(\left(\mathrm{g} / \mathrm{m}^{3} / \mathrm{s}\right)\right. \\
Q_{L} & = & \text { debit per unit area horizontal pada } \\
& = & \text { sumber }\left(\mathrm{m}^{3} / \mathrm{s} / \mathrm{m}^{2}\right) \\
C_{L} & = & \\
& &
\end{array}
$$

Penyelesaian persamaan adveksi - dispersi tersebut menggunakan skema eksplisit, third order finite difference ((Ekebjærg dan Justesen, 1991; Leonard, 1979, 1991). Solusi dari persamaan tersebut akan menunjukan arah persebaran sedimen serta proses perubahan dasar perairan yang terjadi. Mengacu dari persamaan adveksi/dispersi. Suku deposisi dan erosi dipengaruhi oleh hubungan interaksi aliran dan dasar saluran tersebut dinyatakan dalam tegangan geser dasar/bed shear stress $\left(\tau_{b}\right)$. 


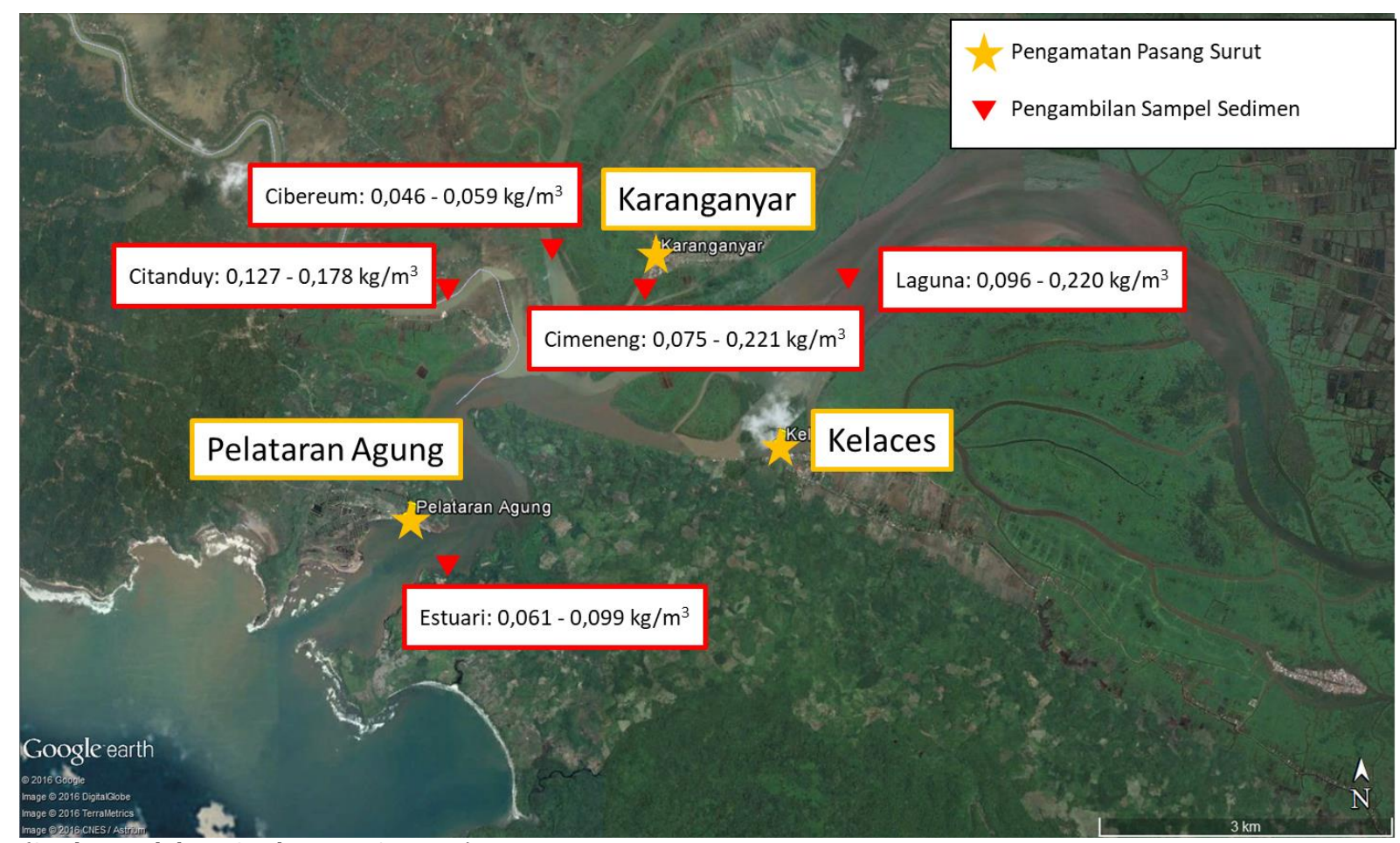

(Sumber: Puslitbang Sumber Daya Air, 2016)

Gambar 3 Konsentrasi Sedimen Layang pada Laguna Segara Anakan pada Survei Tanggal 12 - 14 April 2016

Untuk daerah yang terlindung seperti Laguna Segara Anakan, proses fisik yang terjadi didominasi oleh pasang surut dan aliran sungai. Sehingga interaksi aliran dan dasar saluran hanya dipengaruhi oleh kecepatan arus aliran. Bed shear stress diformulasikan sebagai berikut:

$\tau_{c}=\frac{1}{2} \rho f_{c} v^{2}$

Dimana:

$$
\begin{aligned}
f_{c} & =2\left[2.5\left(\ln \ln \left(\frac{30 h}{k}\right)-1\right)\right]^{-2} \ldots . . \\
h & =\text { kedalaman perairan }(\mathrm{m}) \\
k & =\text { kekasaran dasara perairan }(-)
\end{aligned}
$$

Proses erosi terjadi ketika tegangan geser dasar akibat aliran lebih besar dari tegangan geser dasar kritis untuk terjadi erosi $\left(\tau_{c e}\right)$. Untuk dasar perairan yang tekonsolidasi padat erosi dinyatakan sebagai berikut (Partheniades, 1965):

$S_{E}=E\left(\frac{\tau_{b}}{\tau_{c e}}-1\right)^{n} ; \tau_{b}>\tau_{c e}$

Sedangkan untuk dasar perairan sebagian terkonsolodasi lunak dinyatakan sebagai berikut (Parchure \& Mehta, 1985):

$S_{E}=E \exp \exp \left[\alpha\left(\tau_{b}-\tau_{c e}\right)^{\frac{1}{2}}\right] ; \tau_{b}>\tau_{c e}$

Dimana:

$$
\begin{aligned}
S_{E} & =\text { laju erosi }\left(\mathrm{g} / \mathrm{m}^{2}\right) \\
E & =\text { tingkat kemudahan tererosi dasar } \\
& \text { perairan }\left(\mathrm{g} / \mathrm{m}^{2} / \mathrm{s}\right) \\
n & =\text { faktor kuatnya erosi }(-)
\end{aligned}
$$

\section{$\alpha=$ koefisien erosi $(\mathrm{m} / \sqrt{N})$}

Sedangkan proses sedimentasi terjadi ketika aliran mendekati kondisi batas laminar. Pada model ini didefinisikan dengan kondisi ketika tegangan geser dasar lebih kecil dari tegangan geser kritis untuk terjadi deposisi $\left(\tau_{c d}\right)$. Formulasi matematis untuk laju deposisi dinyatakan sebagai berikut (Krone, 1962):

$S_{D}=w_{s} c_{b} p_{d}$

Dimana $p_{d}=1-\frac{\tau_{b}}{\tau_{c d}} ; \tau_{b} \leq \tau_{c d}$

Dengan:

$$
\begin{aligned}
& S_{D} \quad=\text { laju deposisi }\left(\mathrm{g} / \mathrm{m}^{2}\right) \\
& w_{S} \quad=\text { kecepatan settling/jatuhnya } \\
& \text { sedimen }(\mathrm{m} / \mathrm{s}) \\
& c_{b} \quad=\quad \text { konsentrasi sedimen layang } \mathrm{di} \\
& \text { dasar perairan }\left(\mathrm{g} / \mathrm{m}^{3}\right) \\
& p_{d} \quad=\text { probabilitas terjadinya } \\
& \text { pengendapan }(-)
\end{aligned}
$$

Kecepatan settling dipengaruhi oleh butiran sedimen. Pada sedimen kohesif, material dapat menggumpal (flokulasi) dan memiliki kecepatan settling (jatuh mengendap) yang rendah. Oleh karenanya kecepatan settling pada sedimen kohesif akan dipengaruhi oleh konsentrasi dari sedimen layangnya (Dyer, 1989). Hubungan antara kecepatan settling dengan konsentrasi sedimen layang dinyatakan dengan persamaan berikut (Burt, 1986): 
$w_{s}=k c^{m}$

Dengan $\mathrm{k}$ dan $\mathrm{m}$ adalah parameter yang dicari secara empiris.

\section{Skematisasi Model dan Kondisi Batas}

Kawasan laguna yang menjadi domain model didiskretisasi menjadi elemen - elemen tidak terstruktur (segitiga), dan diformulasikan menggunakan metode finite volume dengan tiap elemen disusun dari tiga node. Skema eksplisit digunakan untuk integrasi waktu.
Diskritisasi wilayah studi dan lokasi kondisi batasnya ditunjukkan pada Gambar 4. Wilayah studi didiskritisasi menjadi 6.946 node yang membentuk 11.014 elemen dengan luas elemen terbesar adalah 247.532,3 $\mathrm{m}^{2}$ dan luas elemen terkecil 19,4 $\mathrm{m}^{2}$.

Daerah hulu disimulasikan dengan input debit konstan yang membawa sedimen layang yang juga diasumsikan konstan. Sedangkan daerah hilir model

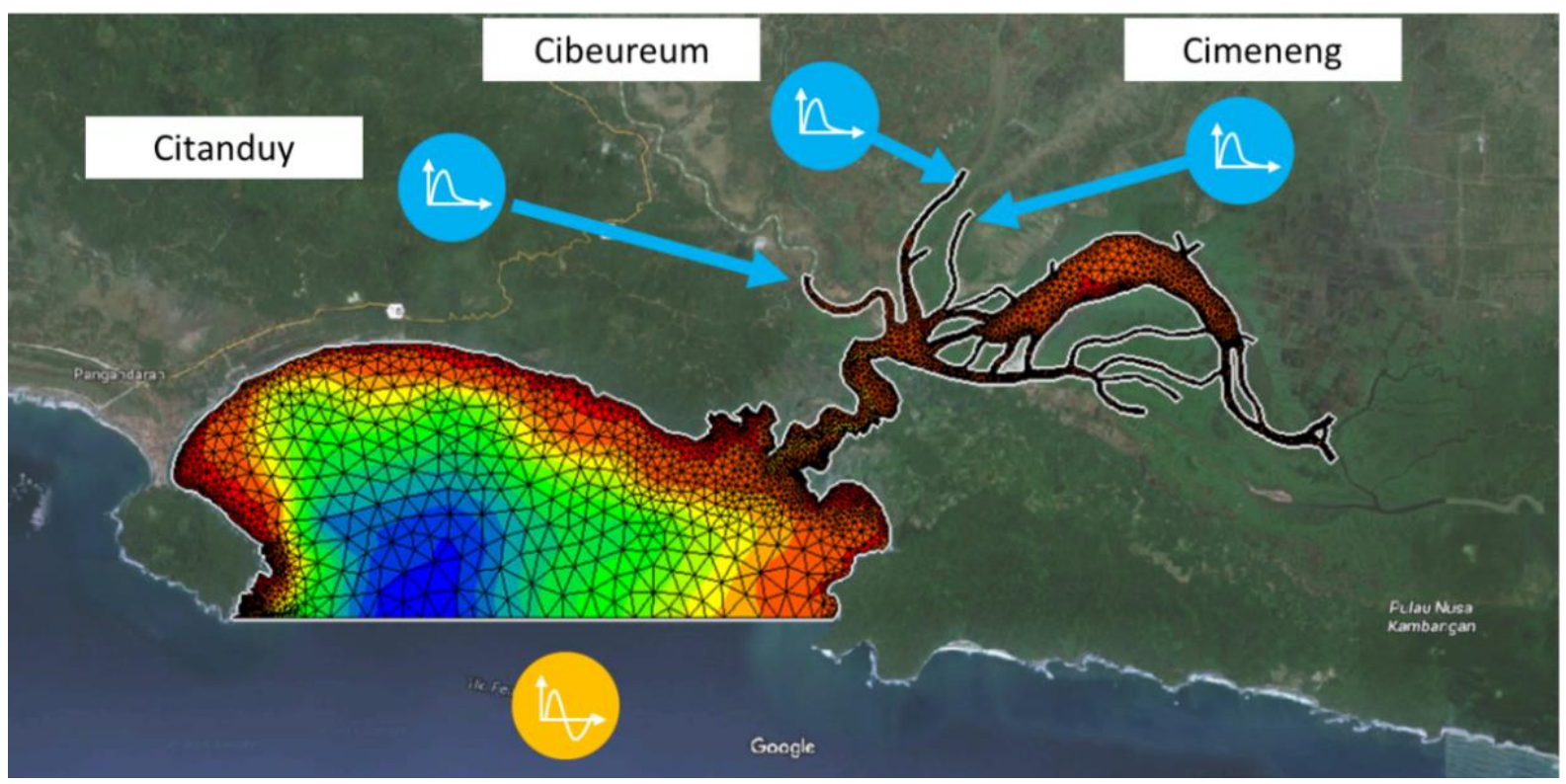

Gambar 4 Diskritisasi dan Syarat Batas Model Numerik Laguna Segara Anakan

berupa elevasi muka air yang fluktuatif akibat pasang surut. Kemudian simulasi dilakukan untuk meninjau proses morfologi dalam jangka waktu satu tahun. Akan tetapi simulasi jangka panjang memerlukan sumber daya komputasi yang besar, maka dilakukan skematisasi pada model sehingga didapat hasil yang cukup representatif dan mempersingkat waktu pacu simulasi.

Skematisasi waktu simulasi dilakukan dengan meninjau faktor terkait waktu yang dapat disimplifikasi. Kondisi batas model adalah debit dan konsentrasi yang konstan di hulu dan pasang surut yang berulang di hilir. Dengan sifat input model yang demikian maka fenomena pada satu siklus kejadian mirip dengan siklus kejadian selanjutnya. Pada kasus ini kejadian siklikalnya adalah pasang surut yang pada model berfungsi sebagai faktor penggerak aliran. Pada umumnya siklus pasang surut ditandai dengan fase bulan yang menyebabkan adanya pasang purnama dan perbani. Satu siklus fase bulan dianggap cukup untuk merepresentasikan beberapa siklus yang terjadi dalam satu tahun kejadian, karena kejadian pasang surut dalam satu tahun masih didominasi oleh konstanta - konstanta yang sama dengan fase satu siklus. Oleh karena itu, simulasi hidrodinamika jangka pendek yang melingkupi satu siklus ini tidak banyak berbeda dengan simulasi satu tahun.

Maka simulasi model hidrodinamika dilakukan untuk 40 dari dengan 10 hari pertama dimaksudkan untuk pemanasan model dan 30 hari selanjutnya untuk menyimulasikan satu siklus fase bulan. Simulasi dimulai dari tanggal 15 Mei 2016 00:00:00, hingga 25 Juni 2016 00:00:00 dengan interval langkah waktu 600 detik.

Untuk dapat menyimulasikan kejadian morfologi selama satu tahun dengan pemodelan hidrodinamik selama satu siklus fase bulan, diperlukan faktor percepatan waktu yang memperbesar respon morfologi yang terjadi akibat angkutan sedimennya. Faktor percepatan waktu yang dipilih adalah 12 karena satu siklus satu bulan umumnya adalah 30 hari, sehingga dengan faktor tersebut kejadian satu tahun dapat direpresentasikan. Dengan faktor tersebut maka 
perubahan kedalaman dalam satu interval waktu akan memberikan nilai yang menggambarkan 12 interval waktu.

\section{Kalibrasi dan Validasi Model}

Model hidrodinamika divalidasi ke data pengukuran elevasi muka air yang ditunjukkan pada Gambar 2 dengan metode Root Mean Square Error (RMSE). Validasi hanya dilakukan untuk parameter elevasi muka air saja.

Kemudian model hidrodinamik ini digunakan sebagai model dasar untuk model angkutan sedimen kohesif. Kalibrasi dan validasi jumlah sedimentasi dilakukan pada model ini.

Pemodelan sedimen kohesif sangat dipengaruhi oleh kondisi unik di lokasi studi yang berakibat belum ada parameter umum yang sudah banyak teruji untuk menyimulasikan suatu wilayah (Andersen dan Pejrup, 2001; Edelvang dan Austen, 1997; Pejrup et al, 1997). Asumsi banyak digunakan dalam penentuan parameter pada model ini, sehingga banyak parameter yang dapat digunakan menjadi parameter kalibrasi.

Parameter tegangan geser dasar kritis untuk deposisi (critical bed shear stress for deposition, $\tau_{c d}$ ) dan parameter tegangan geser dasar kritis untuk erosi (critical bed shear stress for erosion, $\tau_{c e}$ ) merupakan parameter yang memberikan respon secara langsung dan berpengaruh banyak dalam menentukan pola dan volume pengendapan yang terjadi pada model. Oleh karenanya kedua parameter ini sering digunakan menjadi parameter kalibrasi utama untuk memvalidasi model sebelum masuk pada parameter lainnya (Lumborg dan Windelin, 2003; Yuanita et al, 2011). Parameter tersebut yang pada akhirnya digunakan sebagai parameter kalibrasi pada studi ini sehingga dilakukan analisis sensitivitas pada model sebaran sedimen dengan mengubah parameter tersebut.

Model divalidasi dengan mengacu pada volume sedimen yang mengendap masuk pada area laguna. Volume sedimentasi dari hasil simulasi model dibandingkan dengan volume dari data sekunder, yang pada studi ini mengacu pada hasil studi Binnie Black \& Veatch Ltd (2000) yaitu sebesar 1 juta $\mathrm{m}^{3} /$ tahun. Ketika proses kalibrasi membuat model memberikan hasil volume sedimentasi yang berada pada orde tersebut, model diasumsikan sudah dapat merepresentasikan kejadian persebaran dan pengendapan sedimen di Laguna Segara Anakan. Perhitungan volume sedimen yang mengendap dilakukan dengan mengalikan rata - rata perubahan ketebalan dasar di laguna dengan luasan laguna (600 ha). Untuk mereproduksi volume pengendapan di laguna, analisis sensitivitas dilakukan pada parameter kalibrasi untuk mengetahui respon sedimentasi di laguna. Parameter kalibrasi diatur sampai didapatkan volume sedimen yang terendap sekitar 1 juta $\mathrm{m}^{3}$. Analisis sensitivitas dilakukan dengan kalibrasi parameter $\tau_{c d}$ dari rentang 0,01 - 0,2 $\mathrm{N} / \mathrm{m}^{2}$ dan parameter $\tau_{c e}$ dari rentang $0,3-1 \mathrm{~N} / \mathrm{m}^{2}$. Pemilihan nilai tersebut mengacu pada manual DHI (2012b) yang memberikan rekomendasi nilai $\tau_{c d}$ dan $\tau_{c e}$ untuk berbagai tipe lumpur.

\section{HASIL DAN PEMBAHASAN}

\section{Pola Hidrodinamika Laguna Segara Anakan}

Perbandingan hasil prediksi model dan pengukuran lapangan ditunjukkan pada Gambar 5. Perbandingan pada titik Karanganyar memberikan hasil $\mathrm{RMSE}=23,22 \%$. Kemudian titik Kelaces memberikan hasil RMSE $=21,14 \%$. Sedangkan pada titik Pelataran Agung memberikan hasil RMSE = $16,37 \%$.

Meninjau dari lokasi titik observasi, titik Pelataran Agung berada dekat dengan muara dan merupakan pintu masuk untuk pasang surut, sedangkan untuk titik Karanganyar dan Kelaces berada di dalam laguna. Oleh karena itu, kekurangan amplitudo pada titik Karanganyar dan Kelaces dapat disebabkan dari efek lokasi yang berada ke arah hulu yang memiliki luas penampang dan kedalaman yang lebih sempit sehingga muncul efek amplifikasi nonlinear dari konstituen pasang surut yang tidak terlingkup dari input model.

Akan tetapi merujuk pada pola amplitudo dan fase pasang surut yang masih dapat tercantum dengan baik pada model, model ini dianggap masih cukup mampu untuk menyimulasikan kejadian siklus hidrodinamikanya. Permasalahan terbesar adalah pada kurangnya amplitudo yang berimplikasi pada kecepatan aliran dan pada akhirnya akan mempengaruhi laju perubahan kedalaman dasar perairan. Permasalahan ini akan ditangani dengan mengatur parameter kalibrasi di model sedimen yang memepengaruhi laju erosi dan deposisi. Dasar pengaturannya adalah dengan membuat lebih mudah tererosi atau terdeposisi untuk mengkompensasi kekurangan tegangan dasar akibat kecepatan aliran dari model hidrodinamika yang lebih rendah. 


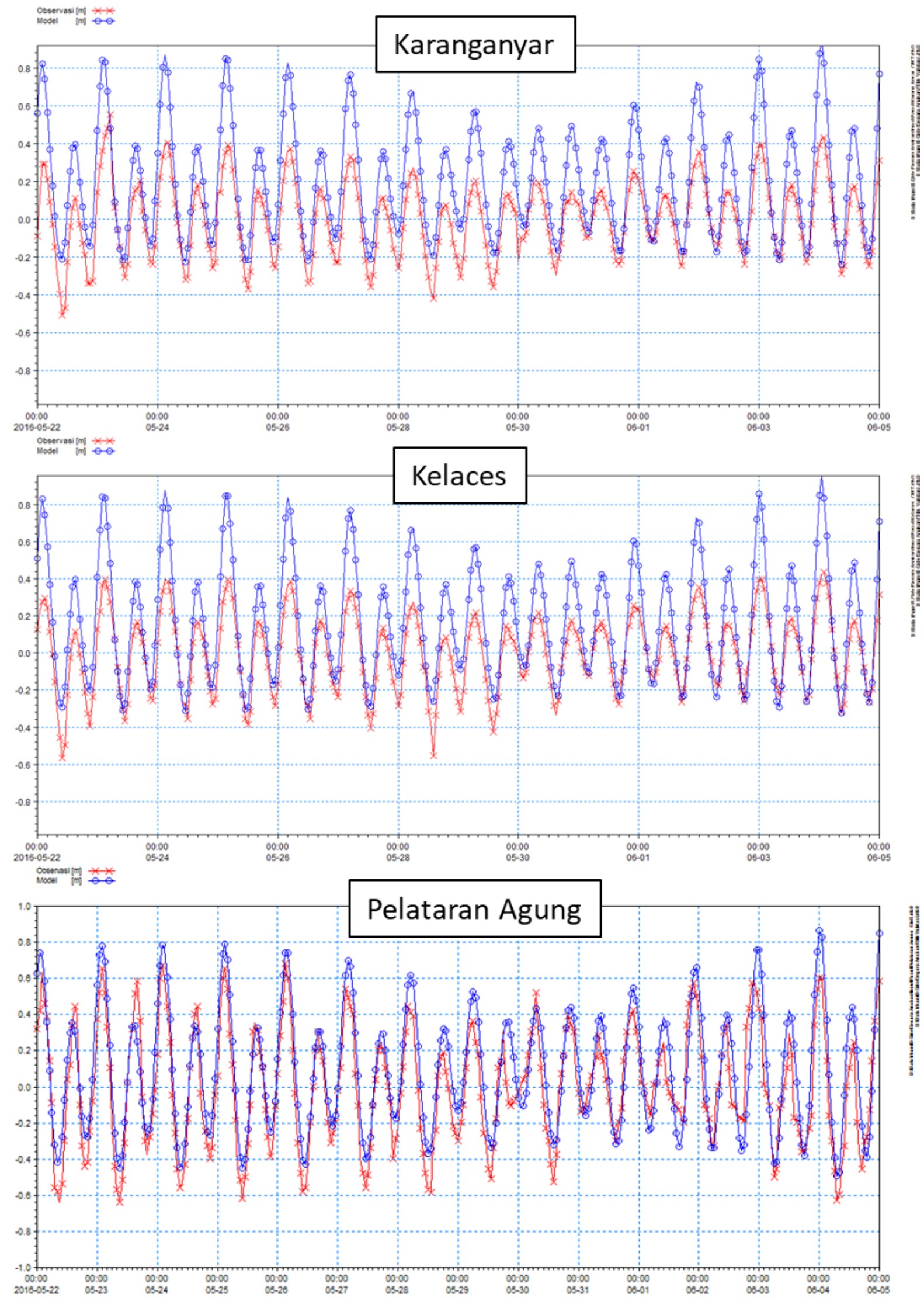

Gambar 5 Perbandingan Elevasi Muka Air Hasil Model (garis biru) dan Pengamatan (garis merah) 
Kemudian pola kecepatan aliran di Laguna Segara Anakan ditunjukkan pada Gambar 6. Pada saat pasang teramati bahwa aliran dari Sungai Citanduy terbawa masuk ke badan laguna akibat terdorong oleh arus pasang. Sedangkan pada saat surut, aliran sungai ini akan mengalir ke laut bersamaan dengan massa air lainnya yang ada di laguna. Kemudian berdasarkan nilai kecepatan arusnya, saat kondisi menuju pasang didapatkan rata - rata kecepatan di daerah Laguna berada di sekitar 0,3 m/s. Sedangakan pada kondisi menuju surut, rata - rata kecepatan aliran $\mathrm{v}$. sekitar $0,2 \mathrm{~m} / \mathrm{s}$

Hasil model tersebut menunjukkan perilaku asimetri pasang surut di Laguna Segara Anakan, yang mengakibatkan arus saat kondisi pasang lebih dominan daripada arus pada saat kondisi surut. Dampaknya, sedimen yang berasal dari sungai akan terbawa jauh masuk ke laguna akibat besarnya arus pasang. Namun, arus surut yang lebih kecil menyebabkan tidak semua sedimen yang terbawa masuk pada saat pasang ini dapat terbawa keluar seluruhnya dari area laguna. Sehingga masih ada sedimen yang tertinggal di area laguna setiap siklus pasang surut terjadi. Kemudian saat masuk ke waktu perubahan aliran dari pasang ke surut dan juga sebaliknya, sedimen yang tertinggal di area laguna akan mengendap karena kecepatan aliran saat di fase ini dapat mendekati nol atau alirannya hampir diam. Konsekuensi dari asimetri pasang surut ini adalah terendapnya sedimen di laguna dikarenakan material sedimen yang dibawa oleh debit Sungai Citanduy cukup signifikan.

\section{Pola Sebaran Sedimen Laguna Segara Anakan}

Model sebaran sedimen menyimulasikan arah sebaran sedimen yang berasal dari Sungai Citanduy. Pada kondisi menuju pasang (Gambar 7), mayoritas sedimen yang berasal dari Sungai Cintanduy akan terbawa masuk ke arah Laguna dan konsentrasinya berada di sekitar $0,22 \mathrm{~kg} / \mathrm{m}^{3}$. Sedangkan saat kondisi menuju surut konsentrasi sedimen di daerah Laguna berada di sekitar 0,06 kg/m $\mathrm{m}^{3}$. Kemudian, bila dibandingkan dengan hasil pengukuran lapangan yang dilakukan oleh Puslitbang Sumber Daya Air (2016) yang diresumekan pada Gambar 3, konsentrasi sedimen pada badan laguna berkisar $96 \mathrm{mg} / \mathrm{L}-220 \mathrm{mg} / \mathrm{L}$ atau sama dengan $0,096 \mathrm{~kg} / \mathrm{m}^{3}-0,22 \mathrm{~kg} / \mathrm{m}^{3}$. Nilai tersebut menunjukkan bahwa hasil dari model berada pada orde yang sesuai dengan data lapangan, sehingga asumsi nilai input konsentrasi yang digunakan dianggap cukup baik untuk menggambarkan kondisi persebaran sedimen di laguna.

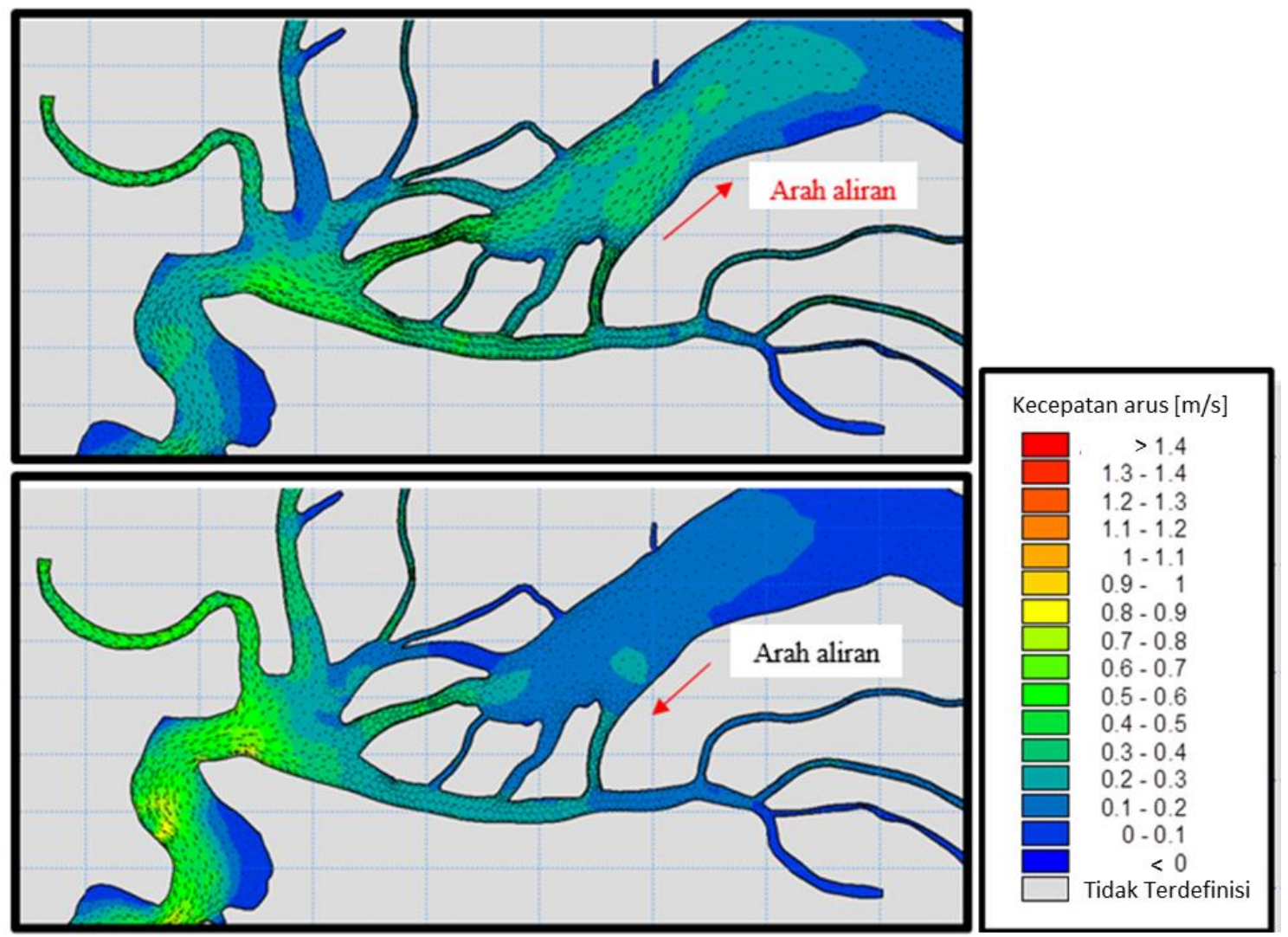

Gambar 6 Pola Kecepatan Arus di Laguna Segara Anakan (atas: Kondisi Menuju Pasang; bawah: Kondisi Menuju Surut 
Dalam pola sebaran sedimen ini terlihat jelas bahwa penyumbang terbesar deposit sedimen di Laguna Segara Anakan adalah sumber yang berasal dari sungai. Konsentrasi sedimen yang terbawa oleh aliran sungai dominan terbawa ke dalam Laguna pada saat pasang, namun pada saat surut tidak semua sedimen yang terbawa oleh aliran pasang dapat terbawa keluar oleh arus saat surut. Untuk kejadian debit yang merepresentasikan kejadian sehari - hari ini menunjukkan bahwa arus sungai tidak cukup kuat untuk melawan arus pasang. Sedangkan pada saat surut hampir semua sedimennya terbawa ke muara. Akan tetapi, akibat kecepatan arusnya tidak sekuat saat pasang sedimen yang masih melayang pada kondisi surut ini dapat terbawa kembali ke laguna sebelum sampai ke laut lepas.

Pasokan sedimen dari sungai ini merupakan sumber sedimen yang menyebabkan pendangkalan di Laguna Segara Anakan. Selama tidak dilakukan rekayasa terhadap sungai untuk mengendalikan sedimen yang masuk ke wilayah laguna, penyempitan Lagunan Segara Anakan tidak dapat terhindarkan karena proses kesetimbangan naturalnya pendangkalan ini terus terjadi.

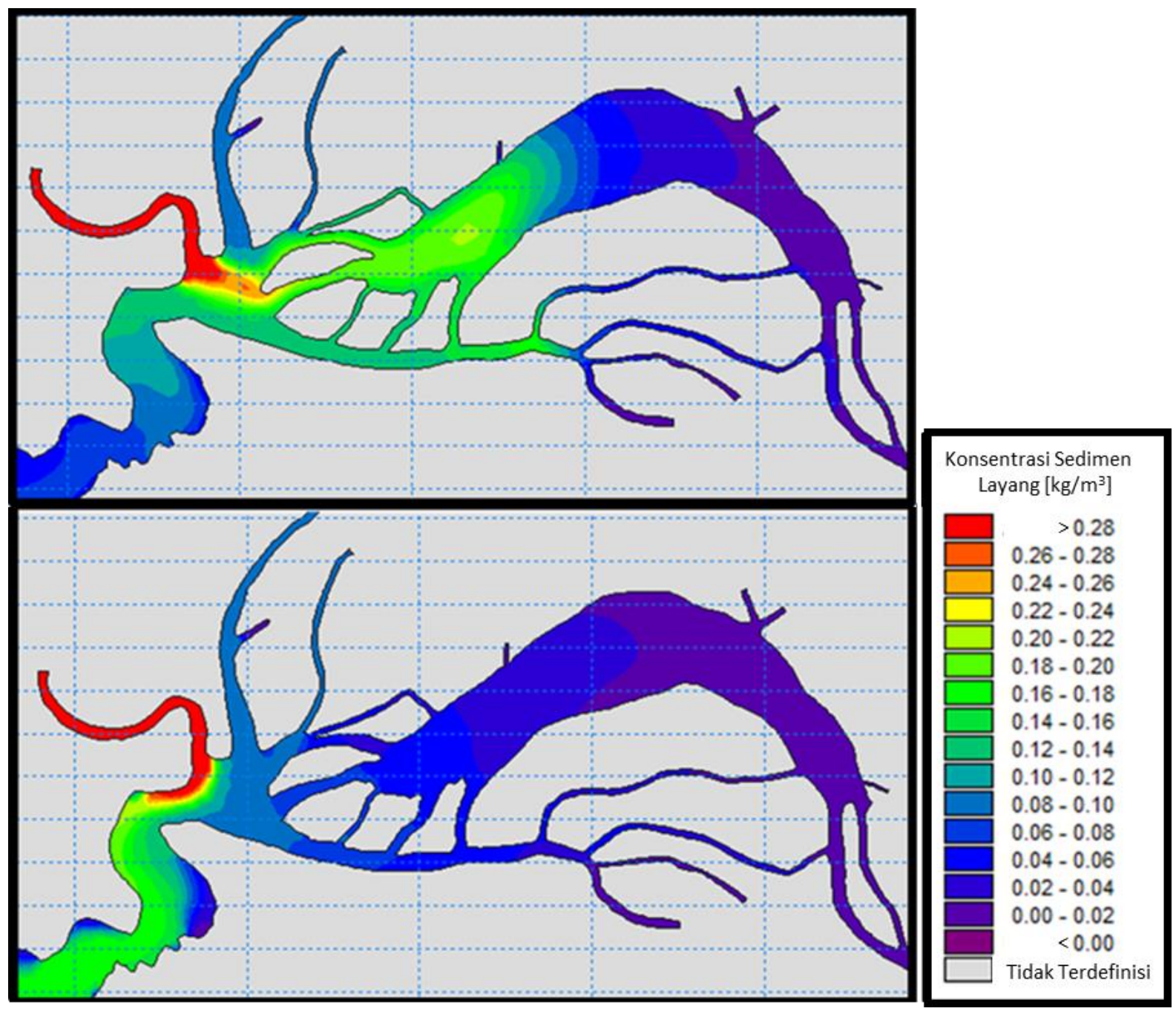

Gambar 7 Pola Sebaran Sedimen di Laguna Segara Anakan (atas: Kondisi Menuju Pasang; bawah: Kondisi Menuju Surut) 


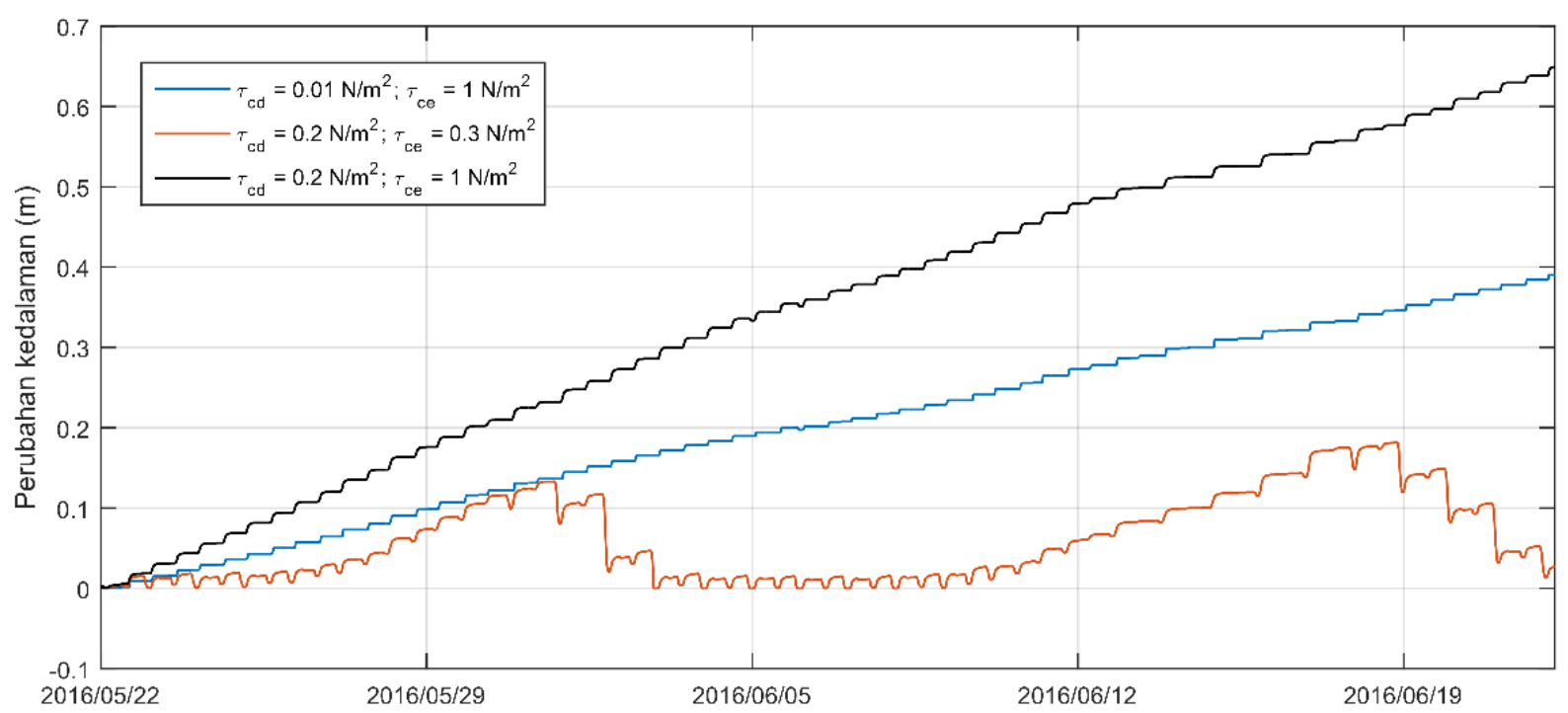

Gambar 8 Perubahan Respon Morfologi terhadap Parameter Kalibrasi

\section{Analisis Sensitivitas Parameter Kalibrasi}

Analisis sensitivitas pada model menunjukkan bahwa paramter $\tau_{c d}$ dan $\tau_{c e}$ yang digunakan sebagai parameter kalibrasi memberikan pengaruh yang besar pada perilaku model (Gambar 8). Parameter $\tau_{c d}$ berpengaruh terhadap volume sedimen yang mengendap di Laguna. Paramter $\tau_{c d}$ berfungsi sebagai parameter batas yang mengatur banyaknya volume sedimen yang terdeposisi dalam satu langkah waktu. Semakin besar parameter tersebut membuat deposisi yang terjadi semakin besar. Kejadian tersebut tergambarkan pada perbandingan nilai $\tau_{c d}$ yang berbeda pada $\tau_{c e}$ yang sama. Dengan membandingkan perbedaan kedalaman yang terjadi pada parameter $\tau_{c d}=0,01$ $\mathrm{N} / \mathrm{m}^{2}$ dan $\tau_{c d}=0,2 \quad \mathrm{~N} / \mathrm{m}^{2}$ yang keduanya disimulasikan pada nilai $\tau_{c e}=1 \mathrm{~N} / \mathrm{m}^{2}$ (garis biru dan hitam), terlihat jelas bahwa nilai $\tau_{c d}$ yang lebih besar menyebabkan respon laju sedimentasi yang lebih besar pada model.

Kemudian kejadian erosi dikontrol oleh parameter $\tau_{c e}$ seperti yang teramati dari perbandingan $\tau_{c e}=0,3 \mathrm{~N} / \mathrm{m}^{2}$ dan $\tau_{c e}=1 \mathrm{~N} / \mathrm{m}^{2}$ pada nilai yang $\tau_{c d}$ sama yaitu $0,2 \mathrm{~N} / \mathrm{m}^{2}$ (garis merah dan hitam). Dasar perairan akan terpengaruh erosi ketika batas kritis terjadinya erosi mampu dilewati tegangan dasar akibat arus aliran. Perubahan kedalaman yang dinamis dapat disimulasikan apabila parameter $\tau_{c e}$ yang didefinisikan berada dalam rentang fluktuasi tegangan dasar akibat pasang surut. Jadi dalam satu fase pasang surut, ada jendela waktu saat nilai batas ini terlewati dan tidak. Ketika nilai $\tau_{c e}$ sangat besar dan tidak dapat terlampaui oleh tegangan dasar, perubahan kedalaman sangat didominasi oleh deposisi seperti yang ditunjukkan oleh hasil simulasi dengan $\tau_{c e}=1 \mathrm{~N} / \mathrm{m}^{2}$. Ketika nilai $\tau_{c e}=0,3$ $\mathrm{N} / \mathrm{m}^{2}$, nilai batas tersebut berada di rentang fluktuasi tegangan dasar akibat pasang surut sehingga dasar perairannya lebih mudah tererosi. Pada kondisi ini tidak teramati adanya penumpukan yang kontinyu seperti yang ditunjukkan pada garis merah pada Gambar 8.

Hubungan antara nilai $\tau_{c d}$ dan $\tau_{c e}$ akan menetukan pola perubahan kedalaman pada model. Dengan batas deposisi yang lebih rendah maka sedimen akan semakin sulit terdeposisi sedangkan batas erosi yang rendah akan membuat dasar perairan lebih mudah tererosi. Pengaturan batas kritis ini, sangat menentukan dinamika morfologi pada model karena akan menyebabkan perubahan kedalaman perairan yang memberikan umpan balik pada pola aliran yang terjadi. Dampak dari perubahan aliran ini akan mempengaruhi kejadian angkutan ke depannya, sehingga pada satu titik pengamatan dapat teramati kejadian deposisi dan atau erosi yang berubah terhadap waktu.

Untuk mendapatkan respon deposisi yang kontinyu pada model, nilai parameter $\tau_{c d}$ harus diperbesar. Namun jumlah maksimum yang dapat terdeposisi pada titik tersebut diatur oleh parameter $\tau_{c e}$. Pendangkalan cenderung menyebabkan naiknya kecepatan aliran yang melewati daerah tersebut sehingga tegangan dasarnya bertambah. Apabila batas kritis erosi ( $\left.\tau_{c e}\right)$ rendah, maka batas tersebut akan mudah dilalui oleh kecepatan aliran yang mengalir di titik tersebut. Ketika batas tersebut dilampaui maka syarat untuk erosi terpenuhi dan model akan memperbarui nilai kedalaman di titik tersebut dengan meninjau efek erosi.

Secara umum, untuk menyimulasikan daerah yang dinamis maka perlu diatur nilai $\tau_{c d}$ dan $\tau_{c e}$ yang berarada pada rentang fluktuasi tegangan dasar. Sedangkan untuk menyimulasikan daerah 
yang cenderung terdeposisi maka nilai $\tau_{c e}$ harus cukup besar. Laju deposisi diatur oleh seberapa besar nilai $\tau_{c d}$.

\section{Kalibrasi dan Perubahan Morfologi Laguna}

Pengendapan di Laguna Segara Anakan diprediksi sebesar 1 juta $\mathrm{m}^{3}$ /tahun berdasarkan hasil studi Binnie Black \& Veatch Ltd (2000). Untuk dapat menyimulasikan kejadian tersebut, respon morfologi yang diharapkan terjadi pada model adalah terjadinya akumulasi deposisi yang menerus terjadi dengan pengaruh erosi yang minim sepanjang waktu simulasi. Untuk mencapai hasil tersebut maka parameter $\tau_{c e}$ diperbesar sehingga erosi sulit terjadi. Pola tersebut tercapai ketika model disimulasikan dengan parameter $\tau_{c e}=1$ $\mathrm{N} / \mathrm{m}^{2}$. Kemudian laju sedimentasi diatur agar volume total sedimentasi yang terjadi selama waktu simulasi mencapai nilai tersebut dan berhasil tercapai dengan pengaturan nilai $\tau_{c d}=0,01 \mathrm{~N} / \mathrm{m}^{2}$. Dengan tercapainya pola akumulasi deposisi dan volume pengendapan, model tersebut diasumsikan sudah dapat menggambarkan kejadian pengendapan di Laguna Segara Anakan. Oleh karena itu hasil model numerik ini dapat digunakan sebagai panduan untuk mencari titik - titik yang mengalami pengendapan terbesar. Titik yang mengalami sedimentasi terbesar merupakan titik kritis yang nantinya akan mempengaruhi pola aliran yang terjadi. Aliran pada titik tersebut cenderung akan melambat sehingga dapat mempercepat terjadinya pendangkalan yang berimplikasi pada penyusutan kawasan laguna.

Berdasarkan hasil model, pengendapan banyak terjadi pada daerah sekitar pulau di laguna (Gambar 9) dengan perubahan kedalaman maksimum sekitar 0,6 $\mathrm{m}$ dan rata - rata perubahan kedalaman dalam waktu satu tahun untuk wilayah laguna berkisar 0,16 m. Pengendapan banyak terjadi di daerah sekitar delta. Daerah ini merupakan daerah yang menjadi jalur keluar masuknya sedimen ke badan laguna. Posisinya yang dekat dari sungai Cintanduy menyebabkan volume sedimen yang terbawa masuk saat pasang sangat tinggi. Kemudian, pada saat surut sedimen sedimen tersebut masih tertinggal di wilayah sekitar pulau. Akibat proses tersebut, sedimen layang banyak tersebar di daerah ini. Kemudian, bentuk celah antar pulau yang seperti selat menyebabkan aliran yang masuk ke celah antar pulau ini cenderung lebih cepat. Namun, begitu aliran tersebut bertemu dengan area dengan penampang yang lebih luas kecepatannya menurun. Penurunan kecepatan ini menyebabkan banyak sedimen yang terbawa arus cepat akan berkumpul di wilayah dekat pulau yang alirannya lebih lambat, sehingga ketika kecepatan alirannya semakin melambat deposisi yang terjadi terfokus pada daerah ini.

Dengan demikian, model ini dirancang sebagai model dasar untuk perencanaan rekayasa teknis di daerah Laguna Sagara Anakan baik dengan metode pengerukan atau dengan rekayasa infrastruktur seperti bangunan pengarah aliran dengan asumsi utamanya adalah sedimentasi yang terjadi di laguna dalam orde 1 juta $\mathrm{m}^{3} /$ tahun. Selama volume sedimentasi yang terjadi di dalam laguna tetap diasumsikan berada pada orde tersebut, model ini dapat memberikan gambaran titik - titik utama tempat terjadinya deposisi serta efektivitas dari rekayasa yang dilakukan. Misalnya meninjau perubahan pola sebaran sedimen dan volume pengendapannya di laguna akibat penggunaan bangunan pengarah atau perubahan pola sedimentasi dan erosi yang terjadi akibat dilakukannya pengerukan.
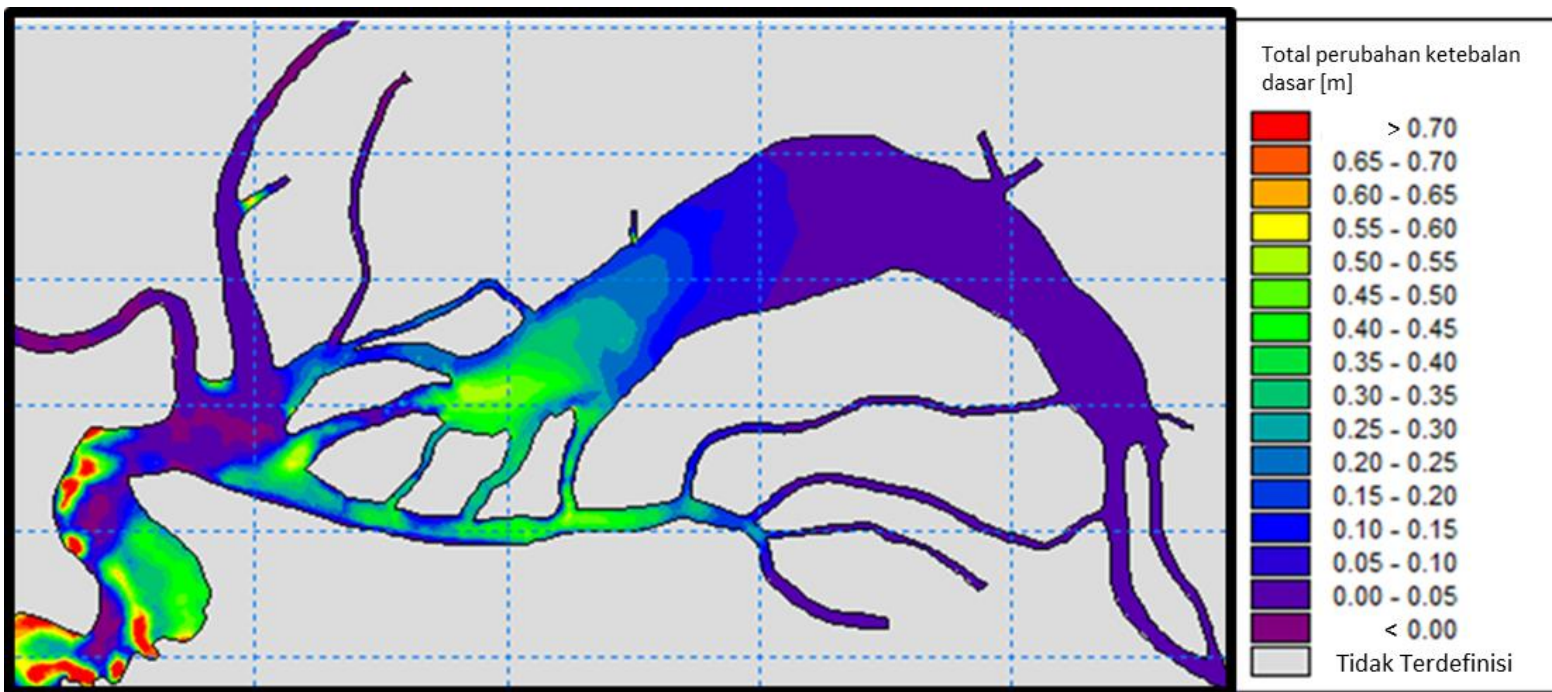

Gambar 9 Perubahan Kedalaman di Laguna Segara Anakan Setelah 1 Tahun 
Akan tetapi, keterbatasan model yang dibangun dengan berbagai asumsi simplifikasi seperti penggunaan debit dan konsentrasi sedimen layang yang konstan sepanjang waktu simulasi menyebabkan pengaruh fluktuasi akibat musim maupun pengaruh tata guna lahan tidak terepresentasikan dengan baik. Oleh karenanya, hasil keluaran yang bersifat kuantifikasi ini tidak dapat memberikan gambaran akurat mengenai jumlah total sedimentasi yang terjadi.

\section{KESIMPULAN}

\section{Kesimpulan}

Penyusutan Laguna Segara Anakan disebabkan oleh asimetri pasang surut di Laguna Segara Anakan, yang mengakibatkan kecepatan arus saat kondisi pasang lebih dominan daripada kecepatan arus pada saat kondisi surut. Dengan kondisi demikian, suplai sedimen dari Sungai Citanduy akan terbawa jauh masuk ke laguna akibat besarnya arus pasang. Kemudian, arus surut yang lebih kecil menyebabkan tidak semua sedimen yang terbawa masuk pada saat pasang dapat terbawa keluar seluruhnya dari area laguna. Sedimen yang tertinggal ini akan mengendap saat aliran melambat akibat perubahan fase dari pasang dan surut maupun sebaliknya.

Pada kajian ini, laju sedimentasi dikontrol oleh parameter kalibrasi $\tau_{c d}$ dan $\tau_{c e}$. Perubahan kedua parameter tersebut menunjukan perubahan yang cukup signifikan pada pola dan volume pengendapan pada model. Volume pengendapan sebesar 1 juta $\mathrm{m}^{3}$ yang berupa prakiraan jumlah besarnya sedimen yang mengendap di kawasan laguna pertahunnya dapat didekati dengan mengatur parameter ini pada model dengan nilai $\tau_{c d}=0,01 \mathrm{~N} / \mathrm{m}^{2}$ dan $\tau_{c e}=1 \mathrm{~N} / \mathrm{m}^{2}$.

Proses pendangkalan yang terjadi terkonsentrasi di sekitar delta dekat muara sungai. Dengan kecenderungan kejadian demikian, diperkiran delta - delta tersebut akan bertambah besar dan pada akhirnya terhubung. Rekayasa teknik untuk mengurangi konsentrasi sedimen yang berakhir di daerah ini dapat membantu mengendalikan laju penyusutan Laguna Segara Anakan. Pengaturan dalam model ini dapat digunakan sebagai acuan dalam kajian rekayasa teknik yang dilakukan, baik dengan skenario pengerukan atau konstruksi bangunan pengendapan sedimen. Kinerja dari rekayasa tersebut dapat dibandingkan dengan kejadian pengendapan pada model ini, sehingga dapat dilakukan penilaian efektivitas dari rekayasa yang dilakukan dalam mengurangi jumlah sedimen yang masuk ke laguna.

\section{Rekomendasi}

Pemodelan sebaran sedimen kohesif dapat menyimulasikan pola persebaran serta volume angkutan dan pengendapan sedimen yang masuk di wilayah Laguna Segara Anakan. Akan tetapi dalam pemodelan ini masih banyak simplifikasi yang dilakukan dengan penggunaan variabel input yang konstan serta parameter - parameter input dasar yang bersifat tipikal. Dalam membuat model yang lebih akurat sebaiknya digunakan data - data yang lebih spesifik tentang lokasi studi seperti data konsentrasi sedimen yang merepresentasikan musim hujan dan kemarau serta adanya data bathimetri untuk beberapa kondisi waktu sehingga validasi model dapat dilakukan dengan membandingkan konsentrasi sedimen yang masuk serta perubahan bathimetrinya.

\section{UCAPAN TERIMA KASIH}

Kajian ini merupakan bagian dari advis teknis untuk penganganan sedimentasi Laguna Segara Anakan pada tahun 2016. Terima kasih tim penulis sampaikan kepada Balai Besar Wilayah Sungai Citanduy dan Puslitbang Sumber Daya Air yang menyediakan dukungan pembiayaan pengumpulan data primer dan penyediaan data sekunder.

\section{DAFTAR PUSTAKA}

Andersen, T. J. \& Pejrup, M. (2001). Suspended sediment transport on a temperate, microtidal mudflat, the Danish Wadden Sea. Marine Geology, 173(1-4), 69-85. https://doi.org/10.1016/S0025-3227(00)00164$\underline{X}$

Ardli, E. R. (2008). A trophic flow model of the Segara Anakan lagoon, Cilacap, Indonesia. UNIVERSITY OF BREMEN.https://elib.suub.uni-bremen.de/ diss/docs/00011000.pdf

Ardli, E. R. \& Wolff, M. (2009). Land use and land cover change affecting habitat distribution in the Segara Anakan lagoon, Java, Indonesia. Regional Environmental Change, 9(4), 235-243. https://doi.org/10.1007/s10113-008-0072-6

BBWS Citanduy. (2012). Kajian Penanganan Sedimen Segara Anakan melalui Check Dam dan Pengerukan. In Workshop Penanganan Segara Anakan. Jakarta.

Binnie Black \& Veatch Ltd. (2000). Segara Anakan Conservation and Developent Project (Water Resources Management \& Sedimentation Control Component) - Hydraulic and Coastal Studies.

Burt, T. N. (1986). Field settling velocities of estuary muds. In Estuarine Cohesive Sediment Dynamics (pp. 126-150). New York: Springer. 
DHI. (2012a). Hydrodynamic and Transport Module Scientific Documentation. Danish Hydraulic Institute.

DHI. (2012b). Mud Transport Module - Scientific Documentation. Danish Hydraulic Institute.

Dyer, K. R. (1989). Sediment processes in estuaries: future research requirements. Journal of Geophysical Research, 94, 14327-14339. https://doi.org/10.1029/JC094iC10p14327

Edelvang, K. \& Austen, I. (1997). The temporal variation of flocs and fecal pellets in a tidal channel. Estuarine, Coastal and Shelf Science, 44(3), 361-367. https://doi.org/10.1006/ecss.1996.0149

Egbert, G. D., Bennett, A. F., \& Foreman, M. G. G.. (1994). TOPEX/POSEIDON tides estimated using a global inverse model. Journal of Geophysical Research, 99(C12). https://doi.org/10.1029/94JC01894

Ekebjærg, L. \& Justesen, P. (1991). An explicit scheme for advection-diffusion modelling in two dimensions. Computer Methods in Applied Mechanics and Engineering, 88(3), 287-297. https://doi.org/10.1016/0045-7825(91)90091-J

Krone, R. B. (1962). Flume Studies of the Transport of Sediment in Estuarial Processes. Berkeley, California: Hydraulic Engineering Laboratory and Sanitary Engineering Research Laboratory.

Leonard, B. P. (1979). A stable and accurate convective modelling procedure based on quadratic upstream interpolation. Computer Methods in Applied Mechanics and Engineering, 19(1), 5998.

https://doi.org/10.1016/0045-7825(79)90034-3

Leonard, B. P. (1991). The ULTIMATE conservative difference scheme applied to unsteady onedimensional advection. Computer Methods in Applied Mechanics and Engineering, 88(1), 1774.

https://doi.org/10.1016/0045-7825(91)90232-U

Lumborg, U., \& Windelin, A. (2003). Hydrography and cohesive sediment modelling : application to the Røm $\varnothing$ Dyb tidal area, 38, 287-303. https://doi.org/10.1016/S0924-7963(02)00247$\underline{6}$

Mehta, A. J., Hayter, E. J. , Parker, R. , Krone, R. B., \& Teeter, A. M. (1989). Cohesive sediment transport. I: Process description. Journal of Hydraulic Engineering, 115(115), 1076/1093.

Parchure, T. M. \& A. J. Mehta. (1985). Erosion of soft cohesive sediment deposits. Journal of Hydraulic Engineering, 111(10), 1308-1326.
Partheniades, E. (1965). Erosion and deposition of cohesive soils. Journal of the Hydraulics Division, 91(1), 105-139.

Pejrup, M., Larsen, M., \& Edelvang, K. (1997). A finegrained sediment budget for the Sylt-Røm $\varnothing$ tidal basin. Helgoländer Meeresuntersuchungen, 51(3), 253. DOI:10.1007/BF02908714

Postma, H. (1967). Sediment Transport and Sedimentation in the Estuarine Environment. American Association of Advanced Sciences, 83, 158-179.

Puslitbang Sumber Daya Air. (2016). Analisis Contoh Air, Sedimen Dasar, Sedimen Layang, Salinitas di Sungai-Sungai Input, Lagoon Dan Estuari Segara Anakan, Cilacap, Jawa Tengah Tanggal 12 - 14 April 2016. Bandung.

Sari, L. K. (2016). Kajian Konektivitas Sedimentasi dan Dampaknya Terhadap Sistem Sosial-Ekologis Laguna (Studi Kasus Laguna Segara Anakan). Institut Pertanian Bogor.

White, A. T., Martosubroto, P., \& Sadorra, M. S. M.. (1989). The coastal environmental profile of Segara Anakan-Cilacap, South Java, Indonesia. Manila, Philippines.

Yuanita, N., Rini, M. A., \& Heriawan, U. (2011). Cohesive Sediment Transport Modeling : Application to the Madura Strait, Indonesia. Conference on Coastal Engineering Practice 2011, 522-536. DOI:10.1061/41190(422)43 